\title{
The Effects of Career Orientations on Entrepreneurial Satisfaction and Business Sustainability
}

\author{
Woo-Seung LEE ${ }^{1}$, Bo-Young KIM ${ }^{2}$
}

Received: July 27, 2019 Revised: September 16, 2019 Accepted: September 24, 2019

\begin{abstract}
This study empirically analyzes how the career orientation factors of startup entrepreneurs affect entrepreneurial satisfaction as well as business sustainability. We propose directions for startup sustainability and development. Based on previous research, we defined the career orientation of entrepreneurs through the five orientation factors of security, autonomy, technical competence, managerial competence, and entrepreneurial creativity. We constructed a research model to determine whether these factors have a causal relationship with entrepreneurial satisfaction or business sustainability through the medium of organizational entrepreneurship. We surveyed startups in Korea using a questionnaire and collected and analyzed a total of 282 points of survey data. The analysis results demonstrated that the entrepreneurial creativity and managerial competence of the members of a startup can play an important role within entrepreneurial satisfaction and business sustainability. Both autonomy and technical competence exhibited no effect on entrepreneurial satisfaction and business sustainability through the medium of entrepreneurship, while security showed a negative effect. In order to improve entrepreneurial satisfaction and achieve business sustainability, we confirmed that it was more important for startups to consider the creativity and business management competences of entrepreneurs rather than pursue business security or have a technology-oriented attitude.
\end{abstract}

Keywords : Startup, Career Orientation, Entrepreneurship, Entrepreneurial Satisfaction, Business Sustainability

JEL Classification Code : M10, M12, M13, M21

\section{Introduction}

Since the recession of 2007, startups have played an important role within job creation. Small and medium sized enterprises (SMEs) account for 95\% of all enterprises in Organisation for Economic Co-operation and Development (OECD) countries. In particular, startups contribute to 60-70\% of new jobs (Mayer-Haug, Read, Brinckmann, Dew, \& Grichnik, 2013). There is a growing social consensus that due to low global economic growth, there are limits in

1 First Author, PhD Canditate, Seoul Business School, aSSIST, South Korea. Email: aurora30@daum.net

2 Corresponding Author, Associate Professor, Seoul Business School, aSSIST, South Korea. [Postal Address: 46 Ewhayeodae2-gil, Seodaemun-gu, Seoul, Korea, 03767] Email: bykim2@assist.ac.kr

(c) Copyright: Korean Distribution Science Association (KODISA) This is an Open Access article distributed under the terms of the Creative Commons Attribution Non-Commercial License (http://Creativecommons.org/licenses/by-nc/4.0/) which permits unrestricted noncommercial use, distribution, and reproduction in any medium, provided the original work is properly cited. supporting the growth of large enterprises and SMEs. Therefore, major countries such as the USA, Japan, and China are actively pursuing policies to cultivate entrepreneurship and startups according to their individual circumstances (Kuckertz, Berger, \& Allmendinger, 2015). For example, in the USA, the Trump administration has issued sustainable support policies including administrative orders for deregulation and has established an Office of American Innovation within the White House Office. Meanwhile, to promote a boom in startups, Japan enacted the law on Supporting Small and Medium Enterprises in 2002 which lowers the minimum capital required for establishing a corporation from JPY 10 million to JPY 1. Since then, private angel investments within early startups increased substantially to JPY 2.5 billion in 2015, while venture capital investments increased to over JPY 90 billion in 2016 (Kogure, Kobayashi, Kawase, Shirasaka, \& Ioki, 2019). In the 2000s, China began to focus on startup related policies and enacted a law to promote SMEs in 2002 (Kwak $\&$ Rhee, 2018). The number of new companies has 
increased rapidly since 2014, with 6.07 million new enterprises established in 2017 (Kwon, 2019).

Korea has also provided various measures, such as the 2009 self-employed creative enterprises promotion strategy and measures in order to promote ventures and startup growth; plans to foster self-employed creative companies within the mobile sector in 2010; global startup promotion measures in 2011; and the 2012 Youth Startup Rechallenge promotion plan. The government's startup support projects totaled KRW 1.18 trillion in 2019 which was an increase of 43.4\% from 2018 (Ministry of SMEs and Startups, 2019). Despite the government's active policies for entrepreneurship and startup support, Statistics Korea (2018) stated that startups in 2016 had a survival rate of $65.3 \%$ after one year since establishment, $50.7 \%$ after two years, and $41.5 \%$ after three years, indicating that more than $50 \%$ of startups disappear within two to three years (Statistics Korea, 2018). This low survival rate represents a vital issue within business sustainability through not only startup establishment but survival and growth, ultimately affecting both individual income and the national economy. For national startup cultivation policies, this indicates that quantitative startup policies must be modified using qualitative measures in order to support startup survival and sustainability.

Recent studies on entrepreneurship tend to emphasize the network and marketing competence of entrepreneurs (Lee \& Ha, 2015). This is because these studies state that startups succumb to the Death Valley of one to three years due to their failure to utilize the available external resources and market-oriented marketing, and instead rely on ideas or technology. CB insights, a U.S. venture capital research firm, surveyed 101 failed startups in 2014 to determine the causes of failure. They found that the largest cause, at $42 \%$, was due to a "no market need" rather than the often-proposed "insufficient capital," which indicates that there was a lack of understanding of the market. Furthermore, we find that the previous literature on the business performance of startups mainly use the entrepreneur's competence and management strategy as independent variables to investigate the relationship with firm performance (Cooper, 1993; Wiklund \& Shepherd, 2005; Yun \& Kim, 2009). However, these studies have limited discussions of the business sustainability of startups. Therefore, it is necessary to further highlight and discuss the key factors that influence entrepreneurial satisfaction, success, and sustainability from various perspectives.

Among the individual characteristics of entrepreneurial factors that affects a startup's business sustainability, this study discusses specific entrepreneurship conditions with a focus on career orientation. Through this, we seek to propose directions for improving entrepreneurial satisfaction and business sustainability. Due to the nature of selfemployed or small-scale startups, the entrepreneur's career orientation can substantially impact the organization's operations or development in accordance with entrepreneurship. In line with current trends that emphasize startup business sustainability, we identify the characteristics of entrepreneurs that affect sustainability in accordance with entrepreneurship and satisfaction. Going beyond the proposals at the individual level, we then provide specific implications for government entrepreneurship education and startup policies.

\section{Literature Review}

\subsection{Entrepreneur Career Orientation}

Drucker (1985) defined entrepreneurship as the innovative act of gathering all existing resources with the intention to create new wealth. The Korea Support for Small and Medium Enterprise Establishment Act defines entrepreneurship as "Establish[ing] new small or mediumsized enterprise," and an entrepreneur as "A person who starts up a small or medium-sized enterprise, or a person who has engaged in his/her business for seven years or less since commencing the business." Entrepreneurship can be considered a new challenge, an adventurous experience, and an opportunity to determine the future by creating a business model that acts as a stimulant for national competitiveness (Wanhill, 2000). However, it is very difficult for entrepreneurs to succeed through enthusiasm for entrepreneurship alone. To achieve success, the competence of a continuous and systematic entrepreneur is needed. This can be regarded as a series of processes over time through the intentional and deliberate actions of the entrepreneur (Bird, 1988). Entrepreneurs are not simply born with an innate competence but can cultivate it through education within their sociocultural context (Chang, 2003).

Research on the individual characteristics of entrepreneurs began in the early 1980s (Yook \& Jeon, 2014). These traits were understood to be the result of behaviors rather than due to the psychology of an entrepreneur. For research into entrepreneurship at the organizational level, entrepreneurship converges into the three areas of innovativeness, proactiveness, and risk-taking, and there is a widespread consensus that entrepreneurship consists of these three components (Covin \& Slevin, 1991; Barringer, 1995). However, the individual characteristics of entrepreneurs can be further divided into background characteristics, psychological characteristics, and environmental characteristics. With regard to background characteristics, researchers have conducted studies based on the entrepreneurs' demographics, such as their gender, age, education, career, and experience (Sexton \& Bowman, 1986; Timmons, 1994). For psychological characteristics, studies have examined various factors including the desire for success, risk-taking, proactiveness, vision, and competence (Lumpkin \& Dess, 1996; Chang, 2000). For environmental characteristics, research has covered entrepreneurial intention or the factors of successful entrepreneurship such as the motivational characteristics, social networks, social 
support forces, role models for successful entrepreneurship, social awareness of entrepreneurs, and so on (Manning, Bieley, \& Norbuen, 1989; Scherer, Adams, Carley, \& Wiebe, 1989).

Researchers have also studied the importance of the term "career" among the individual background characteristics of entrepreneurs (Moneta, 2004). The term "career" has been widely used to describe an individual's career history in relation to his or her work or occupation, as well as a tool to explain the consistency, continuity, or social meaning of life within today's highly complex and diversified society (Oh \& Jyung, 2012). Cornelius, Landstrom, and Persson (2006) described a career as the flow of social paths that individuals have played throughout their lives. They offer that it as a medium that connects individuals to society through its dual internal (self-image and identity) and external aspects (official status, the relationships between authority and obligation, lifestyles). Feldman and Bolino (2005) defined a career as an individual's interrelated work activities that provide continuity, order, and meaning to one's personal life, whereas Baruch \& Rosenstein (1992) defined a career as the overall process that one experiences through work in the duration of a lifetime. The previous literature on "career" uses various terms such as career orientation, career preference, career anchor, and career goal (Schein, 1975; Allen \& Katz, 1986; Delong, 1982; Crant, 1996). While these studies use these terms differently, they hold similar meanings under the same general concept of career orientation.

Career orientation is shaped by one's values, attitudes, talents, and motivations, and requires interaction with others within their social and work experiences (Yun \& Kim, 2009). People are more likely to choose professions and employment that fits their image, or else will transfer to or start a business if they have a job that does not fit their image (Yoon, 2004). Career orientation affects one's career choice regardless of pre-conceived images as based from surroundings, profession, and social experiences (Crant, 1996; Yu \& Yang, 2008). Allen and Katz (1986) and Schein (1996) define career orientation as one's personal perception of career preference, desires related to career choice, values, and talent.

According to Gouldner (1957), career orientation stems from a one-dimensional role distinction between "locals" and "cosmopolitans." He explains that locals possess a strong sense of belonging to their organization, internalize organizational goals as their own, and are interested in promotion within the organization. Since then, many researchers (Gerporrt No Reference 1988; Acs \& Audretsch, 1990; Baugh \& Roberts, 1994) have studied career orientation as based on the concept of locals and cosmopolitans. With recent studies being conducted from various perspectives, Allen and Katz (1986) investigated project career paths that favor challenging tasks, while Bailyn (1991) studied career orientation in paths that link the research results with commercialization. Other studies have focused on research and development and career preferences within various organizations (Farris \& Cordero, 2002; Tremblay, Wils, \& Proulx, 2002; Mallon, Duberley, \& Cohen, 2005).

\subsection{Career Orientation and Entrepreneurship}

Schein (1978) categorized the career anchors that impact individuals' career decisions into five types: security, autonomy, technical competence, managerial competence, and entrepreneurial creativity. Using the term career orientation as a similar concept to career anchor, Delong (1982) proposed nine career orientation types that complemented the career anchor concept as developed by Schein (1978). Among these, autonomy, technical competence, managerial competence, and entrepreneurial creativity had been classified by Schein (1978). However, the anchor of security was divided into regional security and job security, and identity, service, and variety were proposed as additional types. Yoon (2004) conducted a study on the determinants of entrepreneurial intention of Korean business students and graduates and further divided the personal characteristics of career orientation into security orientation, autonomy orientation, technical competence orientation, managerial competence orientation, and entrepreneurial creativity orientation. Yu and Yang (2008) treated career orientation as a factor that was related to entrepreneurial intention, and proposed the following six types of orientations: security, autonomy, technical competence, managerial competence, entrepreneurial creativity, and innovation. In a study on the career orientation and entrepreneurship of Korean SME CEOs, Park and Kim (2015) classified career orientation into the same six categories as Yu and Yang (2008).

\begin{tabular}{|c|c|}
\hline $\begin{array}{c}\text { Key Researchers } \\
\text { (Year) }\end{array}$ & Career Orientation Factors \\
\hline $\begin{array}{l}\text { Schein } \\
(1978)\end{array}$ & $\begin{array}{l}\text { Security, Autonomy, Technical competence, } \\
\text { Managerial competence, Entrepreneurial } \\
\text { creativity }\end{array}$ \\
\hline $\begin{array}{l}\text { Delong } \\
\text { (1982) }\end{array}$ & $\begin{array}{l}\text { Geographical Security, Job security, } \\
\text { Autonomy, Technical competence, } \\
\text { Managerial competence, Entrepreneurial } \\
\text { creativity, Identity, Service, Variety }\end{array}$ \\
\hline $\begin{array}{l}\text { Schein } \\
(1990)\end{array}$ & $\begin{array}{l}\text { Security, Autonomy, Technical competence, } \\
\text { Managerial competence, Entrepreneurial } \\
\text { creativity, Sense of service, Pure challenge, } \\
\text { Life style integration }\end{array}$ \\
\hline $\begin{array}{l}\text { Yoon } \\
(2004)\end{array}$ & $\begin{array}{l}\text { Security, Autonomy, Technical competence, } \\
\text { Managerial competence, Entrepreneurial } \\
\text { creativity }\end{array}$ \\
\hline $\begin{array}{l}\text { Yu and Yang } \\
(2008)\end{array}$ & $\begin{array}{l}\text { Security, Autonomy, Technical competence, } \\
\text { Managerial competence, Entrepreneurial } \\
\text { creativity, Innovation }\end{array}$ \\
\hline $\begin{array}{l}\text { Park and Kim } \\
\quad(2015)\end{array}$ & $\begin{array}{l}\text { Security, Autonomy, Technical competence, } \\
\text { Managerial competence, Entrepreneurial } \\
\text { creativity, Innovation }\end{array}$ \\
\hline
\end{tabular}


Therefore, based on the research of Schein $(1978,1990)$, Yoon (2004), and Park and Kim (2015), this study defines the career orientation of startup entrepreneurs through the following five orientations of: security, autonomy, technical competence, managerial competence, and entrepreneurial creativity. First, the security-oriented entrepreneurs desire an organization that brings business security and long-term stability. They may try to maintain the current organization regardless of its capabilities or acts that may damage its freedom. (Schein, 1978). Startup entrepreneurs, who must pursue change and innovation, may also tend to consider perspectives that ensure stability to secure a future as the organization grows (Kolvereid, 1996).

Second, autonomy-oriented entrepreneurs seek to escape from the organization's regulations and the control of the superiors (Schein, 1978), and they also have a great desire to live the life they want to live (Feldman \& Bolino, 2000). These entrepreneurs pursue a work environment that enables them to work on what they want to, and that uses their preferred methods. Thus, the autonomy-oriented entrepreneurs seek organizations that can provide freedom and autonomy, which is rare within traditional organizations (Feldman \& Bolino, 2000).

Third, the technical competence-oriented entrepreneurs tend to build their careers around specific technical competences (Schein, 1978). As they are interested in careers that enable them to build their expertise in a particular field, these entrepreneurs are more likely to work using technical skills and pursue activities in their own technical areas (Greenberger \& Sexton, 1988). They seek to start or expand their businesses due to a desire to gain recognition as an expert within their area of expertise (Kim \& Yang, 2013).

Fourth, the managerial competence-oriented entrepreneurs are highly interested in managerial roles that allow them to exert authority, power, and influence within an organization. They seek to gain achievements through their efforts and abilities (Schein, 1978). These entrepreneurs measure their success by the size of their managerial responsibilities. Managerial competenceoriented entrepreneurs therefore prefer the opportunity to exercise their managerial competences within their own businesses (Feldman \& Bolino, 2000; Park \& Kim, 2014).

Fifth, the creativity-oriented entrepreneurs desire to create new things (Schein, 1978). Out of this desire to shape their ideas and exercise their creativity, they tend to form their own businesses (Feldman \& Bolino, 2000). While previous studies have indicated that very few people are both entrepreneurially and creatively-oriented (Igbaria, Greenhaus, \& Parasuraman, 1991), these individuals possess a positive attitude towards entrepreneurship that provides opportunities for them to demonstrate their creative talents (Krueger, Reilly, \& Carsrud, 2000).

These career orientations for entrepreneurs directly affect their entrepreneurship (Kim, Bok, \& Park, 2015). Entrepreneurship has been defined as fully capitalizing on available resources in the pursuit of an opportunity to generate value (Stevenson \& Jarillo, 1990). It is based on the balanced leadership and holistic approaches to create new value. This affects personal characteristics of entrepreneurs, such as their way of thinking and behavioral patterns (Timmons, 1994; Morris \& Lewis, 1995). Ultimately, the personal characteristics of career orientation can directly impact entrepreneurship (Park \& Kim, 2014). Based on the previous literature, we established the following hypotheses:

Hypothesis 1: The security orientation of startup entrepreneurs will have a positive effect on entrepreneurship.

Hypothesis 2: The autonomy orientation of startup entrepreneurs will have a positive effect on entrepreneurship.

Hypothesis 3: The technical competence orientation of startup entrepreneurs will have a positive effect on entrepreneurship.

Hypothesis 4: The managerial competence orientation of startup entrepreneurs will have a positive effect on entrepreneurship.

Hypothesis 5: The entrepreneurial creativity orientation of startup entrepreneurs will have a positive effect on entrepreneurship.

\subsection{Entrepreneurship, Entrepreneurial Satisfaction, and Business Sustainability}

Scholars define entrepreneurship differently because it is a topic that has been studied by various disciplines including anthropology, history, economics, sociology, and business administration (Kaufman \& Dant, 1998). While researchers' opinions vary on the concept of entrepreneurship, they generally describe entrepreneurs as innovative, risk-taking, and proactive as based on Miller's (1983) arguments (Rauch, Wiklund, Lumpkin, \& Frese, 2009; Wales, Parida, \& Patel, 2013). Innovativeness can be understood as a firm's efforts and desires to find new opportunities and solutions (Miller, 1983; Covin \& Slevin, 1989; Wiklund \& Shepherd, 2003). Proactiveness refers to an optimistic and goal-oriented orientation, where entrepreneurs strive to gain advantages in new processes and products ahead of competitors (Lumpkin \& Dess, 1996; Wiklund \& Shepherd, 2005). Risk-taking can be understood as the tendency to capture new business opportunities even with no guarantee of business success (Rauch et al., 2009).

Small startups have shown a high correlation between entrepreneurial satisfaction and entrepreneurship. A study on entrepreneurship and entrepreneurial satisfaction found that a CEO's entrepreneurship must be high in order to improve enterprise satisfaction. Hughes and Morgan (2007) defined entrepreneurial satisfaction as the non-financial market, technology, and human resource-related satisfaction after a 
firm's establishment. Zahra (1991) reported that entrepreneurship, as measured through innovativeness, proactiveness, and risk-taking, had a significant relationship to profitability and growth. Lee and $\mathrm{Ha}(2015)$ also found a significant relationship between entrepreneurship and entrepreneurial satisfaction. Rauch et al., (2009) argued that one-dimensional entrepreneurship positively affected entrepreneurial satisfaction. Many other studies (Covin \& Slevin 1991; Zahra 1993; Hornsby No Reference 1993) have recognized that there is a significant relationship between entrepreneurship and entrepreneurial satisfaction.

An enterprise's business sustainability is related to its founder's entrepreneurship. Business sustainability refers to not only its economic self-sufficiency but its stable and sustainable organizational operations through market sales (Wallace, 2005). Lim (2015) defined an enterprise's sustainability by its sustainable employment, sales growth, governmental support (for large enterprises), and competitiveness. Krueger and Carsrud (1993) explained that an entrepreneur's attitude or experience during the process of establishing a company may serve as an important variable in terms of entrepreneurial intention. Therefore, firm growth and sustainability are highly associated with entrepreneurship. Moreover, they are essential for improving a firm's performance and sustainability (Covin \& Slevin, 1991; Zahra, 1991, 1993, Wilkund \& Shepherd, 2011; Jung \& Kim, 2017).

\section{Methodology}

\subsection{Research Model}

This study emphasizes the importance of sustainability for a startup business and discusses how an entrepreneur's career orientation can influence entrepreneurial satisfaction and business sustainability through the medium of entrepreneurship. To this end, we used the five variables of career orientation which comprised of security, autonomy, technical competence, managerial competence, and entrepreneurial creativity orientation as first introduced by Schein (1978), and have featured frequently in previous literature on independent variable career orientation. Rather than classifying the career orientation into the dominant types for each individual, we measured the levels of career orientation while considering the degree of individual difference factors (Yoon, 2004). Through this, we attempted to verify the effect of the entrepreneurs' career orientation on entrepreneurial satisfaction and business sustainability through the medium of entrepreneurship. Using the hypotheses that were derived from the literature review, we designed the research model that is shown in Figure 1. In order to analyze each relationship we selected a path analysis for the structural equation modeling as the research method.

\section{Career Orientation}

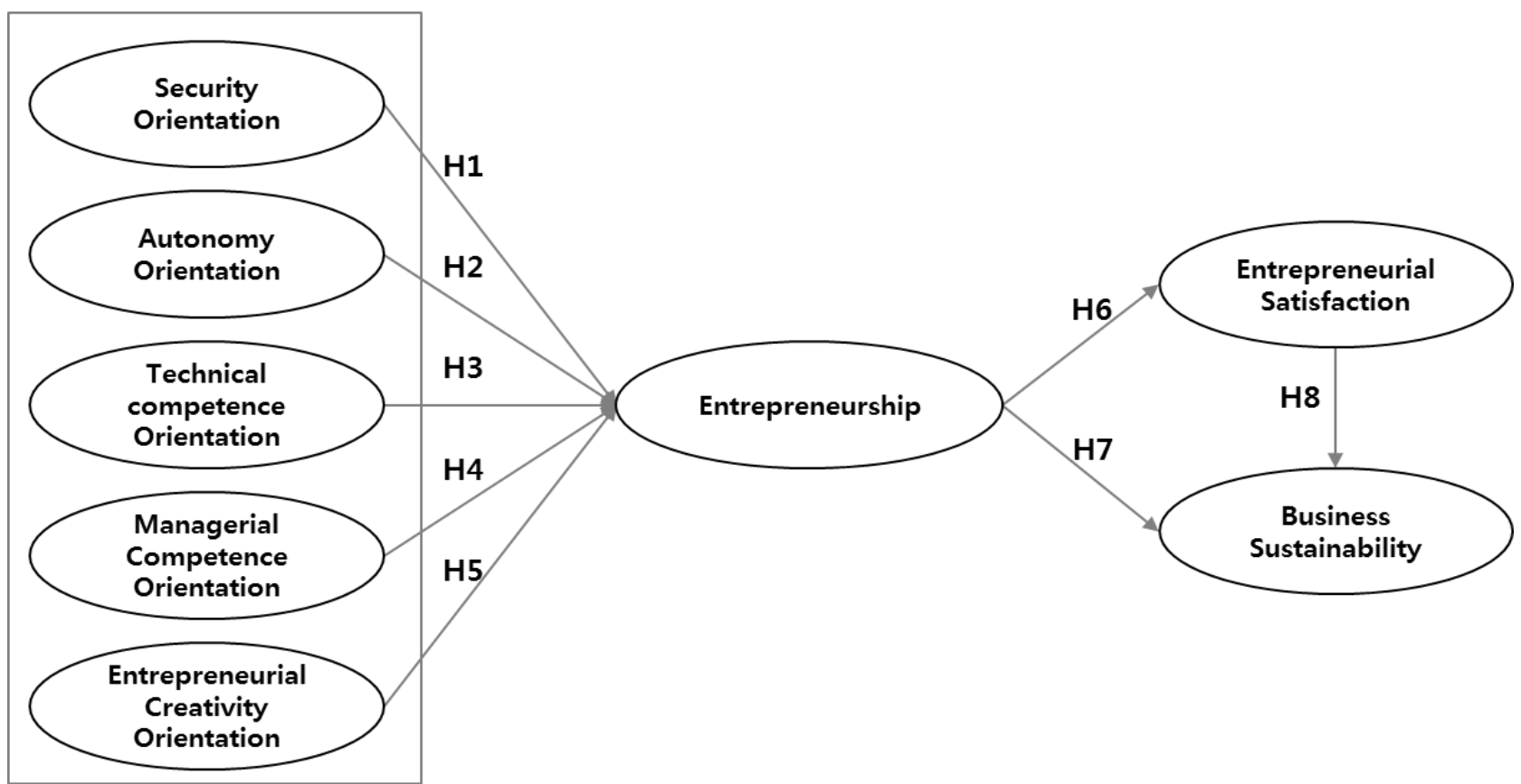

Figure 1: Research Model 


\subsection{Variables and Analytical Approach}

This study conducted a questionnaire to collect the data needed to analyze this model. We measured each variable using the questionnaire. The questions were based on a 5point Likert scale $(1=$ not at all, $5=$ very much so $)$. The operational definitions and questions for each variable were formed as based on the previous research, as shown in Table
2. The operational definitions of the five sub-variables of the independent variable of career orientation were determined with reference to Schein (1990), Yoon (2004), Park and Kim (2015), and Wang, Zhao, Liu, An, and Pan (2019). In addition, we modified the questions that were presented in Schein's (1990) Career Orientation Inventory (COI) using the career orientation measurement tool of Yoon (2004) to fit the purpose of this study.

Table 2: Variable Definition

\begin{tabular}{|c|c|c|c|c|}
\hline \multicolumn{2}{|r|}{ Factors } & Operational Definition & Items & References \\
\hline \multirow{5}{*}{$\begin{array}{l}\text { Career } \\
\text { Orientation }\end{array}$} & Security Orientation & $\begin{array}{l}\text { The tendency to avoid risk and remain within the } \\
\text { organization for life stability. }\end{array}$ & 3 & \multirow{5}{*}{$\begin{array}{l}\text { Schein (1990); } \\
\text { Yoon (2004); } \\
\text { Park and Kim (2015); } \\
\text { Wang et al. (2019) }\end{array}$} \\
\hline & Autonomy Orientation & $\begin{array}{l}\text { The tendency to dislike control and pursue } \\
\text { autonomy. }\end{array}$ & 3 & \\
\hline & $\begin{array}{l}\text { Technical Competence } \\
\text { Orientation }\end{array}$ & $\begin{array}{l}\text { The tendency to continue working in technical } \\
\text { fields rather than be promoted to manager. }\end{array}$ & 3 & \\
\hline & $\begin{array}{l}\text { Managerial Competence } \\
\text { Orientation }\end{array}$ & $\begin{array}{l}\text { The tendency to pursue positions of influence and } \\
\text { power within the organization. }\end{array}$ & 3 & \\
\hline & $\begin{array}{l}\text { Entrepreneurial Creativity } \\
\text { Orientation }\end{array}$ & $\begin{array}{l}\text { The strong intention of self-realization through } \\
\text { entrepreneurship. }\end{array}$ & 3 & \\
\hline \multicolumn{2}{|r|}{ Entrepreneurship } & $\begin{array}{l}\text { Attitude of pursuing innovation in products or } \\
\text { markets and taking risks by proactively coping with } \\
\text { competitors }\end{array}$ & 6 & $\begin{array}{l}\text { Miller (1983); } \\
\text { Zara (1991) }\end{array}$ \\
\hline \multicolumn{2}{|r|}{$\begin{array}{l}\text { Entrepreneurial } \\
\text { Satisfaction }\end{array}$} & $\begin{array}{l}\text { Satisfaction without deficiency felt subjectively by } \\
\text { the entrepreneur regarding startup activities }\end{array}$ & 3 & $\begin{array}{l}\text { Matos and Amaral (2017); } \\
\text { Jung and Kim (2017) }\end{array}$ \\
\hline \multicolumn{2}{|r|}{$\begin{array}{l}\text { Business } \\
\text { Sustainability }\end{array}$} & $\begin{array}{l}\text { Possibility that entrepreneurial performance } \\
\text { (financial, non-financial performance) enough to } \\
\text { sustain business can be made continuously in the } \\
\text { long-term view }\end{array}$ & 5 & $\begin{array}{l}\text { Lim (2015); } \\
\text { Tur-Porcar et al. (2018) }\end{array}$ \\
\hline
\end{tabular}

Through this, we formed three questions for each of the five sub-variables. First, "security orientation" was defined as "the tendency to avoid risk and remain in the organization for life stability," and was measured by the three items of: "preference for stable pay," "preference for stable employment," and "preference for a long-term retirement program." Second, "autonomy orientation" was defined as "the tendency to dislike control and pursue autonomy" and was measured by three items: "preference for free work style," "preference for freedom from regulations and constraints," and "preference to pursue a career independent of time." Third, the "technical competence orientation" was defined as "the tendency to continue working in technical fields rather than be promoted to a manager," and was measured by the three items of: "preference for technical fields," "pursuit of technical knowledge," and "recognition of the importance of technical experience." Fourth, the "managerial competence orientation" was defined as "the tendency to pursue positions of influence and power within the organization," and was measured by the three items of: "hope for the position of supervision and integration," "recognition of the importance of managerial supervision," and "preference for work responsibilities." Lastly, the "entrepreneurial creativity orientation" was defined as "the strong intention of self-realization through entrepreneurship" and was measured by the three items of: "pursuit of new business ideas," "pursuit of my own business," and "recognition of the importance of business experience."

The parameter of "entrepreneurship" means "to pursue innovation in products and markets, proactively respond to competitors, and to take risks." Based on the previous research of Miller (1983) and Zara (1991), this study further divided these factors into innovativeness, proactiveness, and risk-taking. The questionnaire comprised of the following six items: "acceptability of innovative ideas" and "creativity in capturing opportunities" for innovativeness; "active implementation" and "active behavior" for proactiveness; and the "pursuit of new challenges" and the "pursuit of new opportunities" for risk-taking.

Finally, the dependent variable entrepreneurial satisfaction was defined as a "non-financial factor for enjoyable business operations, an enthusiasm for business, a sense of business accomplishment, and the attainment of business stability." Based on the research of Jung and Kim (2017) and Matos and Amaral (2017), we measured entrepreneurial satisfaction through the following three items: "entrepreneurship and satisfaction," "pride as an entrepreneur," and "gladness to be an entrepreneur." The other dependent variable of "business sustainability" was defined as "the possibility of the entrepreneur to continuously create a sufficient business performance in the long term." This definition considers that the ability to sustain employment, service expansions, and growth drivers for the startup to remain financially sustainable is by continuously creating economic profit. Based on Lim (2015) and Tur-Porcar, Roig-Tierno, and Mestre (2018), this study measured business sustainability through the following five items of: "sustainable growth," "sustainable employment," 
"sustainable sales growth," "sustainable investment," and "sustainable competitiveness."

The respondents of the questionnaire were startup entrepreneurs that received support from the Center for Creative Economy and Innovation (CCEI). The sample questionnaire was carried out over 30 days from March 25 to April 24, 2018 and used 17 respondents by region with the cooperation of the CCEI. Of the 297 collected questionnaires, 282 were used for analysis. The respondents of the 15 excluded questionnaires had answered unfaithfully or inappropriately (if they were not the founder). SPSS 24.0 was used to analyze the demographics and descriptive statistics, and to conduct an exploratory factor analysis. AMOS 25.0 was used to perform the confirmatory factor analysis, model verification, and path analysis for the structural equation modeling analysis. Finally, we employed the Sobel Test method to measure the direct, indirect, and total effects, as well as the maximum likelihood estimation (MLE) method to measure the coefficients.

\section{Results}

\subsection{Demographics of the Respondents}

Of the 282 people surveyed, $78.7 \%$ were male; $21.3 \%$ were female; $4.3 \%$ were under the age of $30 ; 28.4 \%$ were in their thirties; $40.1 \%$ were in their forties; and $27.2 \%$ were in their fifties or older. Those in their forties comprised of the largest portion, despite working in startups. In terms of education, $6.7 \%$ had completed high school, $63.1 \%$ had attained an associate or bachelor's degree, and $30.2 \%$ had attained a graduate degree or higher. In terms of the business areas, manufacturing comprised of $37.6 \%$; ICT held $33.7 \%$; and other businesses accounted for $28.7 \%$.

Table 3: Demographics of the Respondent

\begin{tabular}{|c|c|c|c|}
\hline \multicolumn{2}{|c|}{ Class } & Frequency & $\%$ \\
\hline \multirow{3}{*}{ Gender } & Male & 222 & 78.7 \\
\cline { 2 - 4 } & Female & 60 & 21.3 \\
\cline { 2 - 4 } & Total & 282 & 100.0 \\
\hline \multirow{4}{*}{ Age } & Younger than 30 & 12 & 4.3 \\
\cline { 2 - 4 } & $30 \mathrm{~s}$ & 80 & 28.4 \\
\cline { 2 - 4 } & 40s & 113 & 40.1 \\
\cline { 2 - 4 } & Older than 50 & 77 & 27.2 \\
\cline { 2 - 4 } & Total & 282 & 100.0 \\
\hline \multirow{4}{*}{ Education } & High School & 19 & 6.7 \\
\cline { 2 - 4 } & Undergraduate school & 178 & 63.1 \\
\cline { 2 - 4 } & Graduate school & 85 & 30.2 \\
\cline { 2 - 4 } Business & Total & 282 & 100.0 \\
\cline { 2 - 4 } Area & Manufacturing & 106 & 37.6 \\
\cline { 2 - 4 } & IT/Engineering & 95 & 33.7 \\
\cline { 2 - 4 } & Others & 81 & 28.7 \\
\cline { 2 - 4 } & Total & 282 & 100.0 \\
\hline
\end{tabular}

\subsection{Analysis Results of Reliability and Validity}

We analyzed the constructive concepts used through the exploratory and confirmatory factor analyses to ensure the reliability and validity of the research model. For the exploratory factor analysis, one item from each of the security and entrepreneurial creativity orientations, and the sub-variables of the independent variable of career orientation were excluded.

The three items of autonomy orientation, technical competence orientation, and managerial competence orientation were all used. Furthermore, one item from each of the innovativeness and risk-taking components of the parameter for entrepreneurship were excluded. All three items of entrepreneurial satisfaction and the five items of business sustainability (as the dependent variables) were used.

Therefore, we omitted these variables from the measurements and conducted a confirmatory factor analysis as shown in Table 4. The factor loading of all the measurement variables was determined to be .6 or more, which indicated that they could be used as latent variables. For the composite reliability, according to the standard as presented by Bhatnagar, Schiffter, and Coussios (2014), all constructs were deemed to meet the criteria as they were above or approaching .7 or .8 and thus satisfying the threshold. According to the criteria of Anderson and Gerbing (1988), the average variance extracted must be .5 or more, and as all of the constructs in this study ranged from .589-

.769 , they were valid. In addition, all of the measured Cronbach's values were .7 or higher, demonstrating their convergence validity.

We conducted a correlation analysis as shown in Table 4 to confirm the discriminant validity of the constructs and examine the degree of correlation. As based on the criteria proposed by Fornell and Larcker (1981), we confirmed that the square of each correlation coefficient did not exceed AVE, as shown in Table 5, which clearly demonstrated the discriminant validity of the latent variables. 
Table 4: Results of Reliability and Convergent Validity Test

\begin{tabular}{|c|c|c|c|c|c|c|c|}
\hline Category & Variable & $\begin{array}{l}\text { Standard } \\
\text { Loading } \\
\text { Value }\end{array}$ & $\begin{array}{l}\text { Standard } \\
\text { Error }\end{array}$ & t Value & CR & AVE & Cronbach $\alpha$ \\
\hline \multirow{9}{*}{$\begin{array}{l}\text { Independent } \\
\text { Variable }\end{array}$} & \multirow{2}{*}{ Security Orientation } & 0.911 & 0.480 & & \multirow{2}{*}{0.854} & \multirow{2}{*}{0.748} & \multirow{2}{*}{0.854} \\
\hline & & 0.894 & 0.040 & $7.114^{\star \star \star}$ & & & \\
\hline & \multirow[b]{2}{*}{ Autonomy Orientation } & 0.871 & 0.249 & & \multirow[b]{2}{*}{0.909} & \multirow[b]{2}{*}{0.769} & \multirow[b]{2}{*}{0.875} \\
\hline & & 0.912 & 0.106 & $16.059^{\star \star *}$ & & & \\
\hline & \multirow{2}{*}{$\begin{array}{c}\text { Technical Competence } \\
\text { Orientation }\end{array}$} & 0.845 & 0.188 & $9.606^{\star \star \star}$ & \multirow[t]{2}{*}{0.827} & \multirow[t]{2}{*}{0.618} & \multirow[t]{2}{*}{0.748} \\
\hline & & 0.718 & 0.379 & $8.529^{\star \star \star}$ & & & \\
\hline & \multirow{3}{*}{$\begin{array}{l}\text { Managerial Competence } \\
\text { Orientation }\end{array}$} & 0.799 & 0.257 & & \multirow{3}{*}{0.807} & \multirow{3}{*}{0.589} & \multirow{3}{*}{0.727} \\
\hline & & 0.698 & 0.393 & $7.667^{\star \star \star}$ & & & \\
\hline & & 0.796 & 0.376 & $9.464^{\star \star \star}$ & & & \\
\hline \multirow{3}{*}{ Parameter } & \multirow{3}{*}{ Entrepreneurship } & 0.821 & 0.207 & $8.834^{\star * *}$ & \multirow{3}{*}{0.869} & \multirow{3}{*}{0.627} & \multirow{3}{*}{0.765} \\
\hline & & 0.757 & 0.153 & $9.212^{\star \star \star}$ & & & \\
\hline & & 0.701 & 0.460 & $7.893^{\star \star \star}$ & & & \\
\hline \multirow{8}{*}{$\begin{array}{l}\text { Dependent } \\
\text { Variable }\end{array}$} & \multirow{3}{*}{$\begin{array}{l}\text { Entrepreneurial } \\
\text { Satisfaction }\end{array}$} & 0.836 & 0.495 & & \multirow{3}{*}{0.851} & \multirow{3}{*}{0.659} & \multirow{3}{*}{0.814} \\
\hline & & 0.780 & 0.174 & $11.561^{\star \star \star}$ & & & \\
\hline & & 0.646 & 0.280 & $11.068^{* \star *}$ & & & \\
\hline & \multirow{5}{*}{ Business Sustainability } & 0.776 & 0.162 & & & & \\
\hline & & 0.778 & 0.251 & $14.681^{* * *}$ & & & \\
\hline & & 0.874 & 0.098 & $17.398^{\star \star \star}$ & 0.923 & 0.708 & 0.879 \\
\hline & & 0.758 & 0.504 & $11.871^{\star \star \star}$ & & & \\
\hline & & 0.769 & 0.256 & $13.740^{\star * *}$ & & & \\
\hline
\end{tabular}

Note: ${ }^{*} p<0.05,{ }^{* *} p<0.01,{ }^{* * *} p<0.001$

Table 5: Correlation Matrix and Average Variance Extracted (AVE)

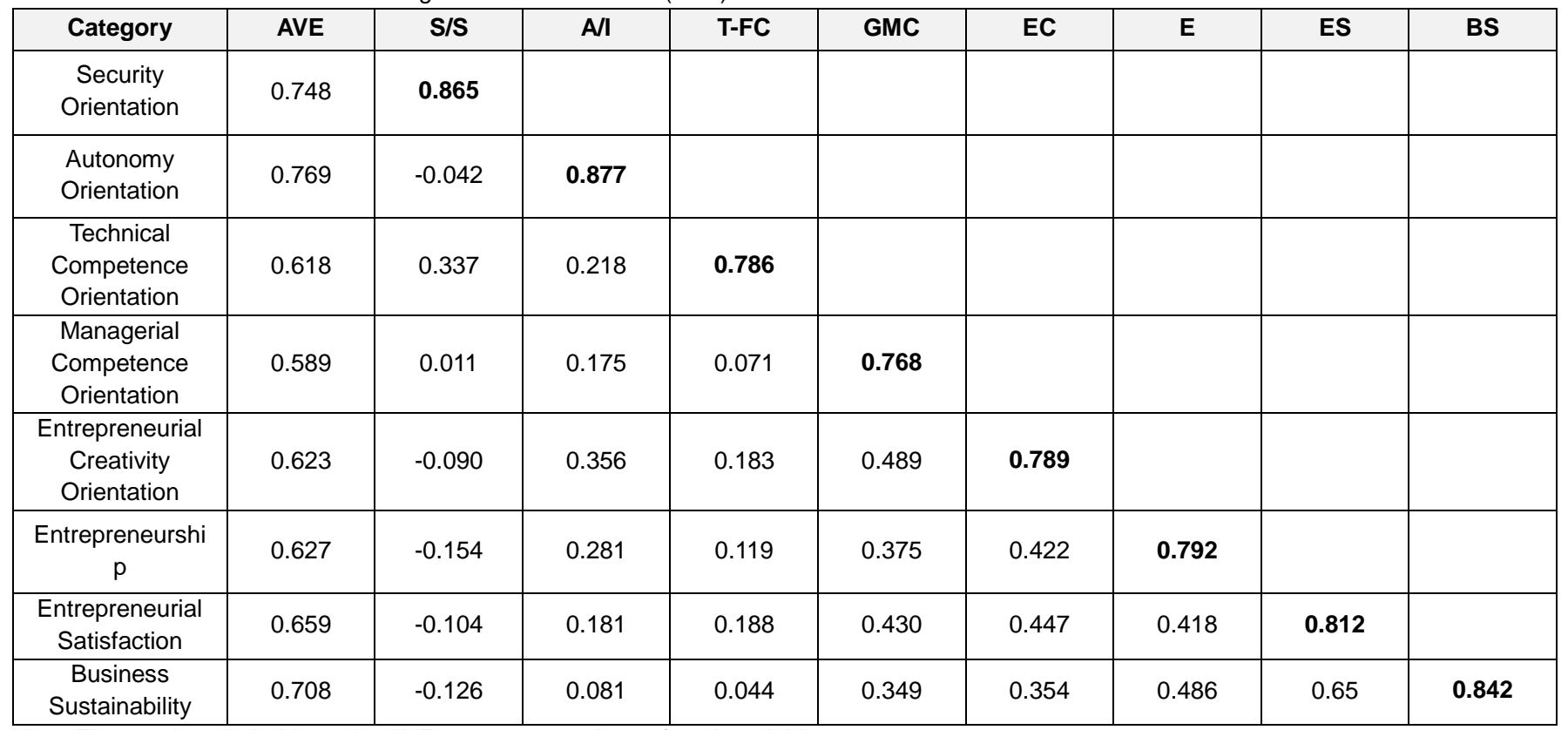

Note: The numbers in bold are the AVE square root values of each variable 


\subsection{Analysis Results of Structural Model}

As shown in Table 5, we examined the fitness index criteria to confirm the model's fit. The model basically met the standard of $1<\mathrm{x}^{2} / \mathrm{d}$.f $<3$ at $\mathrm{x}^{2} / \mathrm{d}$. $\mathrm{f}=2.024$. According to the criteria of $\mathrm{Hu}$ and Bentler (1999), if the goodness-of-fit index (GFI) and the comparative fit index (CFI) are both 9 or more, the model can be considered as fit. In this model, the GFI was slightly less than .9, at 0.872 . However, the CFI was .949 , which indicated significance. Thus, AGFI $=.837$, $\mathrm{NFI}=.847$, and RESEA $=.060$, which does not meet the criteria as proposed by Brown (2014). However, as approximate values were obtained, we can consider the model to be fit overall.

Table 6: Model Fit Indices for the Structural Models

\begin{tabular}{|c|c|c|c|c|c|c|c|c|c|c|c|}
\hline Model & $x^{2}(p)$ & $d f^{1}$ & p & $x^{2} / d f$ & RMR & GFI & AGFI & NFI & TLI & CFI & RMSEA \\
\hline $\begin{array}{c}\text { Original } \\
\text { Model }\end{array}$ & 518.253 & 256 & 0.000 & 2.024 & 0.049 & 0.872 & 0.837 & 0.847 & 0.900 & 0.915 & 0.060 \\
\hline
\end{tabular}

${ }^{1}$ Degree of freedom

As shown in the hypothesis verification in Table 7, the security orientation ( $\mathrm{T}$ value $=-2.650 * *$ ) which was a subvariable of career orientation exhibited a negative effect on entrepreneurship. The managerial competence orientation $(\mathrm{T}$ value $=2.727^{* *}$ ) and the entrepreneurial creativity orientation $(\mathrm{T}$ value $=2.753 * *)$ showed positive effects on entrepreneurship. The autonomy orientation $(\mathrm{T}$ value $=$
1.169) and technical competence orientation $(\mathrm{T}$ value $=$ 1.216) did not affect entrepreneurship. Furthermore, entrepreneurship positively affected both entrepreneurial satisfaction $(\mathrm{T}$ value $=5.168 * * *)$ and business sustainability $(\mathrm{T}$ value $=3.814 * * *)$. In particular entrepreneurial satisfaction $(\mathrm{T}$ value $=6.640 * * *)$ had $\mathrm{a}$ positive effect on business sustainability (Figure 2).

Table 7: Results of Hypothesis Test

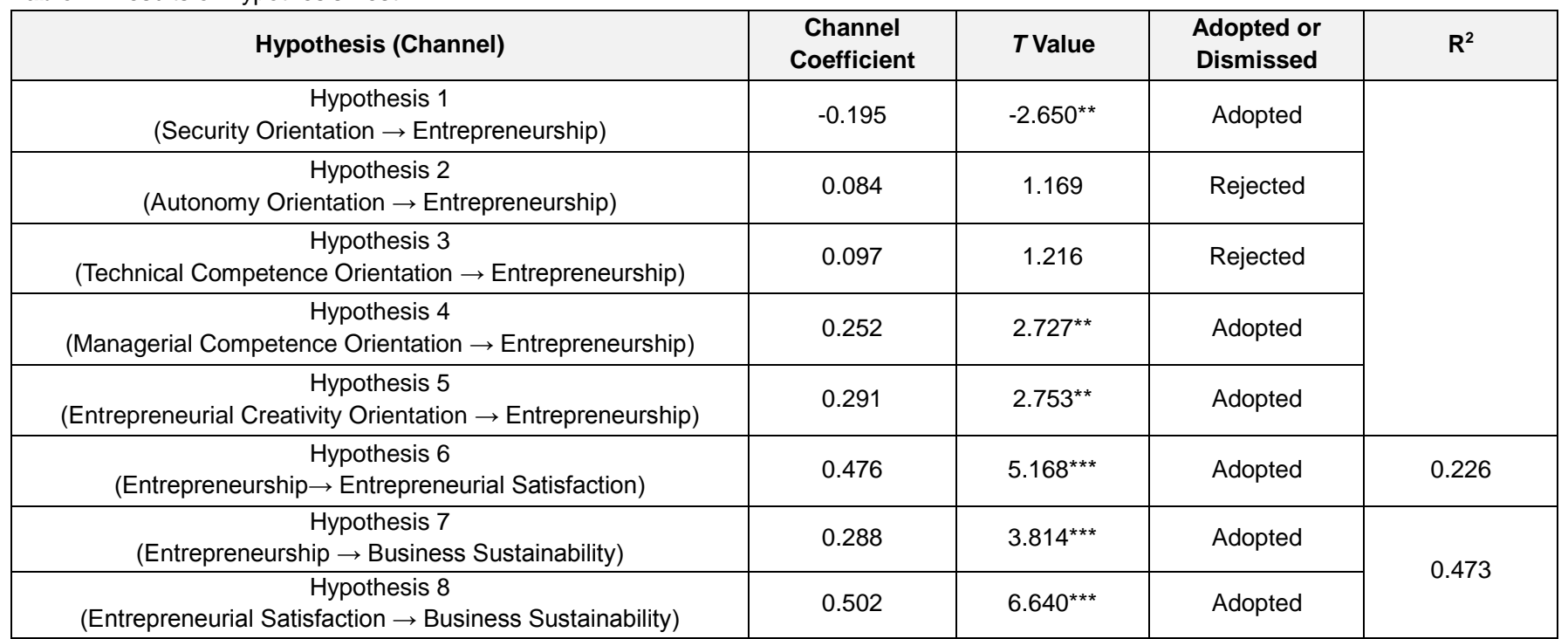

Note: ${ }^{*} p<0.05,{ }^{* *} p<0.01,{ }^{* * *} p<0.001$ 
Career Orientation

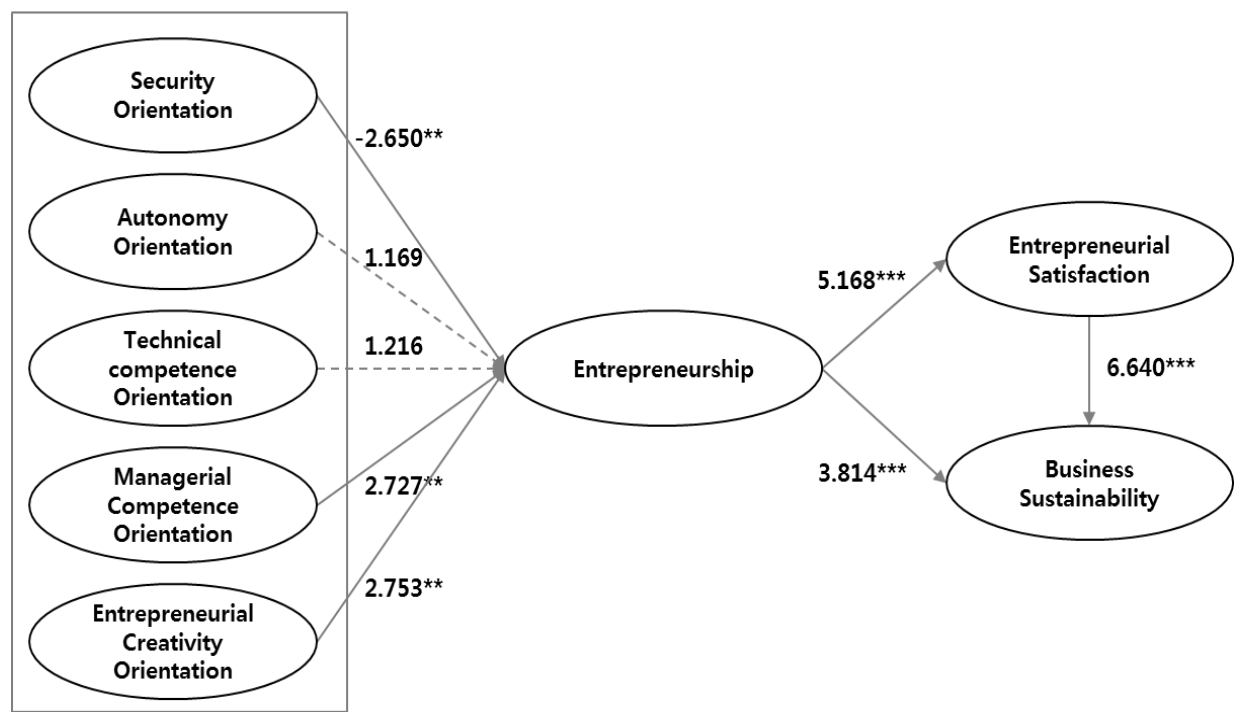

Figure 2: SEM (structural equation model) analysis of research model

(Note: ${ }^{*} p<0.05,{ }^{* *} p<0.01,{ }^{* \star *} p<0.001$ ).

\subsection{Mediated Effect}

To verify the significance of indirect effects, we calculated the direct, indirect, and total effects using the Sobel Test method, which calculates statistics through standard error. As shown in Table 8, security orientation, a sub-variable of career orientation, had a negative indirect effect on entrepreneurial satisfaction through the medium of entrepreneurship (Sobel $\mathrm{z}=-2.377 *$ ). Moreover, the managerial competence orientation and entrepreneurial creativity orientation exhibited positive indirect effects on entrepreneurial satisfaction through entrepreneurship (Sobel $\mathrm{z}=2.431$ *, Sobel $\mathrm{z}=2.416 *$ ).

The security orientation also showed a negative indirect effect on business sustainability through entrepreneurship (Sobel $\mathrm{z}=-2.192 *$ ), while the managerial competence orientation and entrepreneurial creativity orientation showed positive indirect effects on business sustainability (Sobel $\mathrm{z}=$ 2.234*, Sobel $z=2.223 *$ ). Furthermore, entrepreneurship not only directly affected business sustainability but also showed a positive indirect effect through entrepreneurial satisfaction (Sobel z $=4.068 * * *$ ).

Table 8: Results of Indirect, Direct, and Total Effects

\begin{tabular}{|c|c|c|c|c|}
\hline $\begin{array}{l}\text { Dependent } \\
\text { Variable }\end{array}$ & Explanatory Variable & Direct Effect & Indirect Effect & Total Effect \\
\hline \multirow{3}{*}{$\begin{array}{l}\text { Entrepreneuri } \\
\text { al Satisfaction }\end{array}$} & Autonomy Orientation & - & 0.040 (Entrepreneurship) & 0.040 \\
\hline & Managerial Competence Orientation & - & $0.120^{\star}$ ( Entrepreneurship) & 0.120 \\
\hline & Entrepreneurial Orientation & - & $0.139^{\star}$ ( Entrepreneurship) & 0.139 \\
\hline \multirow{4}{*}{$\begin{array}{c}\text { Business } \\
\text { Sustainability }\end{array}$} & Security Orientation & - & $-0.098^{*}$ ( Entrepreneurship) & -0.098 \\
\hline & Managerial Competence Orientation & - & $0.127^{\star}$ ( Entrepreneurship) & 0.127 \\
\hline & Entrepreneurial Creativity Orientation & - & $0.146^{*}($ Entrepreneurship) & 0.146 \\
\hline & Entrepreneurship & $0.288^{* * *}$ & $\begin{array}{c}0.239^{\star \star \star} \\
\text { (Entrepreneurial Satisfaction) }\end{array}$ & 0.527 \\
\hline
\end{tabular}

Note: ${ }^{*} p<0.05,{ }^{* *} p<0.01,{ }^{* * *} p<0.001$

\section{Conclusion}

This study sought to discuss how the career orientation factors of entrepreneurs affected entrepreneurship, entrepreneurial satisfaction, and business sustainability within a social environment where startups create new growth engines and opportunities for individuals. The results demonstrated that a managerial competence orientation and entrepreneurial creativity orientation positively affects 
business sustainability through the medium of entrepreneurship. Conversely, the hypotheses for the technical competence orientation and autonomy orientation were not supported, as they showed no effect. Thus, as opposed to technical competence and autonomy-oriented characteristics, more business-friendly factors such as managerial and business-oriented characteristics have a larger impact on entrepreneurial satisfaction and business sustainability for startups.

Previous studies on venture firms and entrepreneurship have discussed a technical competence orientation as an important factor (Gao, Zhou, \& Yim, 2007; Kim \& Yang, 2008). However, recent studies (Park \& Kim, 2015; Jung, 2016) have reported extensive results that demonstrate that the technical competence-oriented factors do not have a significant effect on entrepreneurship or startup success. Thus, in a shifting entrepreneurship and market environment for startups, we concluded that entrepreneurs should emphasize business competences rather than technical innovation or expertise related factors. Past studies have also emphasized an autonomy orientation as an important factor to enhance creativity and innovation for venture firms and startups through a horizontal organizational culture and business environment (Hackman \& Oldham, 1976; Lee, 1998). Recent studies (Lee \& Wong, 2004; Park \& Kim, 2015) suggest that as work environments improve and business environments, that ensure autonomy, spread in the midst of social and organizational change, an autonomy orientation was shown to not have a significant effect on entrepreneurship, entrepreneurial intention, and so on. This finding corresponds to previous results.

The security orientation showed a negative effect. Here, security orientation can reduce entrepreneurial satisfaction and business sustainability when mediated by entrepreneurship, such as the innovativeness and proactiveness required by startups. Consequently, unlike the employees of general companies, startup entrepreneurs must always be wary of security orientation. Career orientation is one's self-image that relates to their profession and is formed by a combination of talent, ability, desire, motivation, attitude, and values. Career orientation is formed through various life experiences and feedback from others and is relatively unchanging and stable throughout one's lifetime (Schein, 1978). This study additionally found that the career orientation of an entrepreneur affects entrepreneurial satisfaction and startup continuity through entrepreneurship. These research findings suggest the following implications. First, individual entrepreneurs should regard their career orientation to be as important a factor as entrepreneurship and pursue the necessary orientation from the perspective of the members who run the organization.

As indicated in this study, entrepreneurial creativity orientation and managerial competence orientation are both important for entrepreneurs and should be continuously developed to cultivate business sense and management ability. Second, this study carries implications not only for startup entrepreneurs but also for potential (prospective) entrepreneurs. Potential entrepreneurs, including college students concerned about their future career, or office workers dreaming of starting a business, must deeply understand their career orientation.

As shown in the results of this study, the technical competence and autonomy orientations had no effect on entrepreneurship and do not have a significant effect on entrepreneurial satisfaction and business sustainability. Thus, individuals should be wary of the idea that a startup is a suitable career simply because one has a strong technical competence orientation (e.g., a passionate interest in a new technology) or a strong autonomy orientation (e.g., a desire to escape from the regulations and constraints of supervisors). Third, this study also suggests implications for policy managers who design various support policies to promote startups. We found that managerial competence orientation affected startup sustainability as much as entrepreneurial creativity orientation did. This is likely due because operating and sustaining a business is a comprehensive activity that requires holistic management. Therefore, programs can be enhanced to cultivate not only entrepreneurial creativity orientation but also managerial competence orientation in government education, as well as mentoring support programs and education that emphasizes the importance of managing tasks such as planning, human resources, and finances.

Nevertheless, this study has the following limitations. First, this study suffers from generalization as we derived the analytical results based on the questionnaire data of Korean startups. It is therefore necessary to perform generalization and comparative analysis studies by expanding the questionnaire to different continents and countries, thereby ensuring the reliability and validity of the research. Second, this study limited career orientation to the five factors of: security orientation, autonomy orientation, technical competence orientation, managerial competence orientation, and entrepreneurial creativity orientation. Future studies should expand and derive career orientation factors that are more suited to today's changing environment and startup characteristics. This will enable us to investigate the career orientations of the startup members other than the founders. Finally, this study is limited in that it generalizes the startups of various industries. However, due to the nature of startup industries, these have widely different business models and characteristics, depending on their ecosystem and environment. Future studies should further divide the personal characteristics of entrepreneurs that affect career orientation and the startup industry (manufacturing, IT, services, and so on), thereby promoting the development of research.

\section{References}

Acs, Z., \& Audretsch, D. B. (1990). Innovation and small firms. Cambridge, MA: MIT Press. 
Allen, T. J., \& Katz, R. (1986). The dual ladder: Motivational solution or managerial delusion? $R \& D$ Management, 16(2), 185-197.

Anderson, J. C., \& Gerbing, D. W. (1988). Structural equation modeling in practice: A review and recommended two-step approach. American Psychological Association, 103(3), 411-423.

Bailyn, L. (1991). The hybrid career: An exploratory study of career routes in R\&D. Journal of Engineering and Technology Management, 8, 1-14.

Barringer, B. R. (1995). The performance implications of achieving a fit between corporate entrepreneurship and strategic management practices (Doctorial dissertation, University of Missouri).

Baruch, Y., \& Rosenstein, E. (1992). Career planning and managing in high tech organizations. International Journal of Human Resource Management, 3, 477-496.

Baugh, S. G., \& Roberts R. M. (1994). Professional and organizational commitment among engineers; Conflicting or complementing? IEEE Transactions on Engineering Management, 41, 108-114.

Bhatnagar, S., Schiffter, H., \& Coussios, C. (2014). Exploitation of acoustic cavitation-induced microstreaming to enhance molecular transport. Journal of Pharmaceutical Sciences, 103(6), 1903-1912.

Bird, B. (1988). Implementing entrepreneurial ideas: The case for intention. Academy of Management Review, 13(3), 442-453.

Brazeal, D. (1993). Organizing for internally developed corporate ventures. Journal of Business Venturing, 8(1), 75-90.

Chang, D. S. (2000). A study on the entrepreneurship education and entrepreneurial intension of college students in business and engineering. Industrial Research, 12, 63-82.

Chang, D. S. (2003). Building strategy for successful venture creation education in Korea by reviewing venture creation education of Korea and USA. Journal of the Korea Society of Computer and Information, 8(1), 129-139.

Cheong, Y. H., \& Ha, K. S. (2012). A study on individual characteristic factors affecting entrepreneurial intentions of startup business candidate, Korea Research Academy of Distribution and Management Review, 15(4), 41-53.

Cooper, A. C. (1993). Challenges in predicting new firm performance. Journal of Business Venturing, 8(3), 241253.

Cornelius, B., Landstrom, H., \& Persson, O. (2006). Entrepreneurial studies: The dynamic research front of a developing social science. Entrepreneurship Theory and Practice, 30(3), 375-398.

Covin, J. G., \& Slevin, D. P. (1989). Strategic management of small firms in hostile and benign environments. Strategic Management Journal, 10(1), 75-87.

Covin, J. G., \& Slevin, D. P. (1991). A conceptual model of entrepreneurship as firm behavior. Entrepreneurship Theory and Pratice, 16(1), 7-25.
Crant, J. M. (1996). The proactive personality scale as a predictor of entrepreneurial intentions. Journal of Small Business Management, 34(3), 42-49.

Delong, T. J. (1982). Reexamining the Career Anchor Model. Personal, 59(3), 50-61.

Drucker, P. F. (1985). Innovation and entrepreneurship practice and principles. New York, NY: Harper \& Row.

Farris, G. F., \& Cordero, R. (2002). Leading your scientist and engineers 2002. Research-Technology Management, 45(6), 13-25.

Feldman, D. C., \& Bolino, M. C. (2000). Career patterns of the self-employed: Career motivations and career outcome, Journal of Small Business Management, 38(3), 53-67.

Fornell, C., \& Larcker, D. F. (1981). Evaluating structural equation models with unobservable variables and measurement error. Journal of Marketing Research, 18(1), 39-50.

Gao, G. Y., Zhou, K. Z., \& Yim, C. K. (2007). On what should firms focus in transitional economies? A study of the contingent value of strategic orientations in China. International Journal of Research in Marketing, 24, 3-15.

Gerportt, T. J., Domsch, M., \& Keller, R. T. (1988). Career orientations in different countries and companies; An empirical investigation of West German, British and US industrial R\&D professionals. Journal of Management Studies, 25, 439-462.

Gouldner, A.W. (1957). Cosmopolitans and locals: Toward an analysis of latent social roles- I . Administrative Science Quarterly, 2(3), 281-316.

Greenberger, D. B., \& Sexton, D. L. (1988). An interactive model of new venture initiation. Journal of Small Business Management, 26(3), 1-7.

Hackman, J. R., \& Oldham, G. R. (1976). Motivation through the design of work: Test of a theory. Organizational Behavior and Human Performance, 16, 250-279.

Hu, L. T., \& Bentler, P. M. (1999). Cutoff criteria for fit indexes in covariance structure analysis: Conventional criteria versus new alternatives. Structural Equation Modeling, 6(1), 1-55.

Igbaria, M., Greenhaus, J. H., \& Parasuraman, S. (1991). Career orientations of MIS employees: An empirical analysis. MIS Quarterly, 15, 151-169.

Jung, D. S. (2016). An emperical study on factors affecting start-up intention: Focused on individual characteristics and career orientation. Journal of Industrial Economics and Business, 29(4), 1565-1586.

Jung, S. C., \& Kim, Y. J. (2017). An empirical study on the relationship between entrepreneurship and start-up achievement considering moderating effect of government's support policy: For start-up companies in Busan and Kyungnam regions. The Journal of Internet Electronic Commerce Resarch, 17(3), 55-70.

Kaufmann, P. J., \& Dant, R. P. (1998). Franchising and domain of entrepreneurship research. Journal of Business Venturing, 14, 5-16. 
Kim, C. S., \& Yang, Y. I. (2008). The effects of technological orientation, environmental turbulence on product creativity and performance. Korean Management Review, 37(2), 249-268.

Kim, S. H., Bok, K. S., \& Park, J. C. (2015). Relationship among self-determination, entrepreneurship and entrepreneurial intention of university students in Korea. Asia-Pacific Journal of Business Venturing and Entrepreneurship, 10(5), 15-26.

Kim, Y. H., \& Yang. T. Y. (2013). Researching entrepreneurship over the last decade: A challenge for the 21st century. Asia Pacific Journal of Small Business, 35(3), 348-376.

Kogure, Y., Kobayashi, N., Kawase, M., Shirasaka, S., \& Ioki, M. (2019). Proposal of entrepreneur's behavior process for overcoming Japanese type valley of death in startup companies. Review of Integrative Business and Economics Research, 8(Supplementary Issue 3), 102-112.

Kolvereid, L. (1996). Organizational employment versus self-employment: Reasons for career choice intentions. Entrepreneurship: Theory and Practice, 20(3), 23-31.

Krueger, N. F., \& Carsrud, A. L. (1993). Entrepreneurial intentions: Applying the theory of planned behaviour. Entrepreneurship \& Regional Development-An International Journal, 5(4), 315-330.

Krueger, N. F., Reilly, M. D., \& Carsrud, A. L.(2000). Competing models of entrepreneurial intentions. Journal of Business Venturing, 15(5), 411-432.

Kuckertz, A., Berger, E., \& Allmendinger, M. (2015). What drives entrepreneurship? A configurational analysis of the determinants of entrepreneurship in innovationdriven economies. Business Administration Review, 75(4), 273-288.

Kwak, H., \& Rhee, M. (2018). Comparative study of a startup ecosystem in Seoul, Korea and Chengdu, China. Asia-Pacific Journal of Business Venturing and Entrepreneurship, 13(5), 131-154.

Kwon, P. O. (2019). Global Market Report 18-043. Seoul, Korea: KOTRA. I S B N: 979-11-6097-874-2(93320).

Lee, J. W. (1998). Characteristics of successful hightechnology venture companies: A case study. Advancing Small Enterprise Innovation Research, 1(1), 101-125.

Lee, S. H., \& Ha, K. S. (2015). A study on the influence of entrepreneurship and start-up competency on entrepreneurial satisfaction: Focusing on the moderating effect of flow experience. Asia-Pacific Journal of Business Venturing and Entrepreneurship 10(5), 137150.

Lee, S. H., \& Wong, P. K. (2004). An exploratory study of technopreneurial intentions: A career anchor perspective. Journal of Business Venturing, 19, 7-28.

Lim, S. T. (2015). The impact of tourism entrepreneurship on the sustainability in the creative tourism enterprise: The moderating role of government support policy. Korean Journal of Hospitality \& Tourism, 24(5), 21-40.

Lumpkin, G. T., \& Dess, G. G. (1996). Clarifying the entrepreneurial orientation construct and linking it to performance. Academy of Management Review, 21(1), 135-172.

Mallon, M., Duberley, J., \& Cohen, L. (2005). Careers in public sector science: Orientations and implications. $R \& D$ Management, 35, 395-407.

Manning, K., Bieley, S., \& Norbuen, D. (1989). Developing a new venture strategy. Entrepreneurship: Theory and Practice, 14(1), 68-76.

Hughes, M., \& Morgan, R. E. (2007). Deconstructing the relationship between entrepreneurial orientation and business performance at the embryonic stage of firm growth. Industrial Marketing Management, 36(5), 651661.

Matos, C. S., \& Amaral, M. (2017). Entrepreneurial satisfaction among senior entrepreneurs: The moderating effect of industry experience and unemployment status. Journal of Business Venturing(Grant number: 649378).

Mayer-Haug, K., Read, S., Brinckmann, J., Dew, N., \& Grichnik, D. (2013). Entrepreneurial talent and venture performance: A meta-analytic investigation of SMEs. Research Policy, 42, 1251-1273.

Miller, D. (1983). The correlates of entrepreneurship in three types of firms. Management Science, 29(7), 770791.

Ministry of SMEs and Start-ups. (2019). Entrepreneurial support notice (No.2019-1). Daejoen, Korea: Ministry of SMEs and Start-ups.

Moneta, G. B. (2004). The flow experience across cultures. Journal of Happiness Studies, 5(2), 115-121.

Morris, M. H., \& Lewis, P. S. (1995). The determinants of entrepreneurial activity : Implications for marketing. European Journal of Marketing, 29(7), 31-48.

Oh, C. H., \& Jyung, C. Y. (2012). Identification of career orientation types and related variables of office workers in large corporations. Journal of Corporate Education and Talent Research, 14(1), 133-154.

Park, J. W., \& Kim, W. J. (2014), A study on the relationships between career orientation, entrepreneurship and the firm performance. The Korean Association of Small Business Studies, 53-74.

Park, J. W., \& Kim, W. J. (2015). The effects of CEO's career orientation on the firm performance: Mediation effect of entrepreneurship. The Korean Small Business Review, 37(2), 69-86.

Rauch, A., Wiklund, J., Lumpkin, G. T., \& Frese, M. (2009). Entrepreneurial orientation and business performance: An assessment of past research and suggestions for the future. Entrepreneurship Theory and Practice, 33(3), 761-787.

Schein, E. H. (1975). How career anchors hold executives to their career paths. Personal, 52(3), 11-24.

Schein, E. H. (1978). Career dynamics: Matching individual and organizational needs. Boston, MA: Addison-Wesley.

Schein, E.H. (1990). Career anchors: Discovering your real values. San Diego, CA: Pfeiffer \& Company. 
Schein, E. H. (1996). Career anchors revisited: Implications for career development in the 21st century. Academy of Management Executive, 10, 80-88.

Scherer, R. F., Adams, J. S., Carley S. S., \& Wiebe, F. A. (1989). Role model performance effects on development of entrepreneurial career preference. Entrepreneurship: Theory and Practice, 13(3), 53-71.

Sexton, D. L., \& Bowman, N. B. (1986). The entrepreneur: A capable executive and morce. Journal of Business Venturing, 1(1), 129-140.

Statistics Korea. (2018). Startup survival and extinction report. Daejeon, Korea: Statistics Korea.

Stevenson, H. H., \& Jarillo. J. C. (1990). A paradigm of entrepreneurship: Entrepreneurial management, Strategic Management Journal, 11(4), 17-27.

Timmons, J. (1994). New venture creation: Entrepreneurship for the $21^{\text {st }}$ century, Fourth Edition. Boston, MA: McGraw Hill.

Tremblay, M., Wils, T., \& Proulx, C. (2002). Determinants of career path preferences among Canadian engineers. Journal of Engineering and Technology Management, 19, $1-23$.

Tur-Porcar, A., Roig-Tierno, N., \& Mestre, A. L. (2018). Factors affecting entrepreneurship and business sustainability. Sustainability, 10, 452.

Wallace, B. (2005). Exploring the meaning(s) of sustainability for community-based social entrepreneurs. Social Enterprise Journal, 1(1). ISSN: 1750-8614.

Wales, W. J., Parida, V., \& Patel, P. C. (2013). Too much of a good thing? Absorptive capacity, firm performance, and the moderating role of entrepreneurial orientation. Strategic Management Journal, 34(5), 622-633.

Wanhill, S. (2000). Small and medium tourism enterprises. Annals of Tourism Research, 27(1), 132-147.

Wang, J., Zhao, Q., Liu, T., An, M., \& Pan, Z. (2019).
Career orientation and its impact factors of general practitioners in Shanghai, China: A cross-sectional study. BMJ Open 2019;9:e21980. doi:10.1136/bmjopen-2018021980.

Wiklund, J., \& Shepherd, D. (2003). Knowledge-based resources, entrepreneurial orientation, and the performance of small and medium-sized businesses. Strategic Management Journal, 24(13), 1307-1314.

Wiklund, J., \& Shepherd, D. (2005). Entrepreneurial orientation and small business performance: A configurational approach. Journal of Business Venturing, 20(1), 71-91.

Yook, C. H., \& Jeon, I. O. (2014). Effect of entrepreneur's characteristics on the intention of entrepreneruship: Focusing on the moderating effect of entrepreneurship mentoring in Korean. Journal of the Korea Contents Association, 14(10), 661-676.

Yun, J. R., \& Kim, H. C. (2009). The effect of entrepreneurs characteristics on performance. Productivity Review, 23(4), 401-427.

Yoon, B. S. (2004). Determinants of entrepreneurial intentions: Individual characteristics and environmental factors. Korean Business Review, 17(2), 89-1110.

Yu. Y. H., \& Yang, D. W. (2008). An empirical study of factors affecting entrepreneurial intention: Focused on career orientation, social \& cultural perception, and entrepreneurial support programs. Korea Journal of Business Administration, 21(5), 2347-2368.

Zahra, S. A. (1991). Predictors and financial outcomes of corporate entrepreneurship: An exploratory study. Journal of Business Venturing, 6(4), 259-285.

Zahra, S. A. (1993). Environment, corporate entrepreneurship, and financial performance: A taxonomic approach. Journal of Business Venturing, 8(4), 319-340. 